\title{
ANALISIS IMPLIKATUR PADA KOLOM MANG USIL DALAM SURAT KABAR HARIAN KOMPAS DAN IMPLIKASINYA DALAM PEMBELAJARAN BAHASA INDONESIA DI SMA
}

\author{
Syahru Ramadan, Helena Emma Maria M., dan Usman \\ Fakultas Bahasa dan Sastra, Universitas Negeri Makassar \\ Jalan Daeng Tata Raya, Kampus Parangtambung, Makassar \\ Email: syahru.ramadan.unm@gmail.com
}

\begin{abstract}
Analysis of Implicature in Column Mang Usil in Kompas Daily Newspapers and Their Implications in Learning Indonesian in High School. The purpose of this research was to (1) describe the form of implicatures in Column Mang Usil at Kompas Newspaper, (2) describe the function of implicature in Column Mang Usil at Kompas Newspaper. This research is a qualitative descriptive study analyzing Mang Usil corner column in Kompas Daily Newspapers. Instruments used in this research is researcher and matrix form and function implicatures. Data in this research is written utterances contained in Mang Usil column in the Kompas Daily Newspaper June 2015, while the data source of this research is the Kompas Daily Newspaper. Data collection technique used in this research is the technique of reading, and record. The result showed that (1) the form of implicatures obtained in Column Mang Usil at Kompas Daily Newspapers consists of three types: declarative sentences consisting of declarative active and passive, imperative sentences consisting of imperative ordinary and prohibitions, and interrogative, (2) Function implicatures obtained in Column Mang Usil at Kompas Daily Newspapers consists of seven types, which function in the form of statements, functions in the form of satire, functions in the form of criticism, functions in the form of appreciation, functions such as support, functions in the form of a ban, and functions such as command, (3) the results of this study can be implicated in learning Indonesian Language in senior high school that is in the learning activities anecdotes text as one alternative learning resources in producing the text anecdotes on high school students grade X.
\end{abstract}

\begin{abstract}
Abstrak. Analisis Implikatur pada Kolom Mang Usil dalam Surat Kabar Harian Kompas dan Implikasinya dalam Pembelajaran Bahasa Indonesia di SMA. Penelitian ini bertujuan untuk (1) mendeskripsikan wujud implikatur dalam Kolom Mang Usil pada Surat Kabar Harian Kompas, (2) mendeskripsikan fungsi implikatur dalam Kolom Mang Usil pada Surat Kabar Harian Kompas. Penelitian ini merupakan penelitian deskriptif kualitatif yang menganalisis kolom pojok Mang Usil dalam Surat Kabar Harian Kompas. Instrumen yang digunakan penelitian ini adalah peneliti dan matriks wujud dan fungsi implikatur. Data penelitian ini ialah tuturan tertulis yang terdapat dalam kolom Mang Usil dalam Surat Kabar Kompas edisi Juni 2015 sedangkan sumber data penelitian ini adalah Surat Kabar Harian Kompas. Teknik pengumpulan data yang digunakan adalah teknik baca, dan catat. Hasil analisis data menunjukkan bahwa (1) wujud implikatur yang diperoleh dalam Kolom Mang Usil pada Surat Kabar Harian Kompas terdiri atas tiga jenis, yaitu : kalimat deklaratif yang terdiri atas deklaratif aktif dan pasif, kalimat imperatif yang terdiri atas imperatif biasa dan larangan, dan interogatif. (2) Fungsi implikatur yang diperoleh dalam Kolom Mang Usil pada Surat Kabar Harian Kompas terdiri atas tujuh jenis, yaitu fungsi berupa pernyataan, fungsi berupa sindiran, fungsi berupa kritikan, fungsi berupa apresiasi, fungsi berupa dukungan, fungsi berupa larangan, dan fungsi berupa perintah. (3) hasil penelitian ini dapat diimplikasikan ke dalam pembelajaran Bahasa Indonesia di SMA yaitu dalam kegiatan pembelajaran teks anekdot sebagai salah satu sumber belajar alternatif dalam memproduksi teks anekdot pada siswa SMA kelas X.
\end{abstract}

Kata Kunci: Implikatur, Kolom Pojok Kompas, Teks Anekdot. 
Peristiwa komunikasi antara dua orang atau lebih atau yang dikenal dengan istilah penutur dan mitra tutur memiliki fungsi, maksud, dan tujuan tertentu. Austin (dalam Arifin, 2002: 4) menyatakan bahwa komunikasi merupakan serangkaian tindak ujar (tindak tutur) yang digunakan secara bersistem untuk menyelesaikan tujuan tertentu atau berbagai tujuan. Isi komunikasi yang disampaikan melalui kata-kata seringkali tidak seluruhnya terkomunikasi karena pengirim pesan biasanya menggunakan kata-kata dalam bentuk tindak tutur tidak langsung literal, yaitu tindak tutur yang diungkapkan dalam modus kalimat yang tidak sesuai dengan maksud pengutaraannya, tetapi tidak dengan kata-kata yang menyusunnya sesuai dengan yang dimaksud penutur. Hal semacam ini dapat dipelajari dengan ilmu pragmatik yang di dalamnya membahas implikatur.

Implikatur menurut Wijana (1996: 38) adalah hubungan antara tuturan dengan yang disiratkan dan tidak bersifat semantik, tetapi kaitannya hanya didasarkan pada latar belakang yang mendasari kedua proposisinya. Rosidi (2009) berpendapat bahwa implikatur percakapan adalah makna yang tersirat melalui ujaran sebuah kalimat dalam sebuah konteks, meskipun makna itu bukan merupakan suatu bagian dari apa yang dituturkan. Dengan demikian, implikatur adalah suatu konsep yang menerangkan bahwa apa yang diucapkan berbeda dengan apa yang dimaksudkan. Ada makna lain dibalik makna tuturan itu.

Implikatur dapat muncul dalam berbagai bentuk, baik lisan maupun tulisan, misalnya dalam percakapan langsung yang terjadi antara penutur dan mitra tutur, maupun seperti pada dialog yang digunakan dalam skenario drama maupun film. Selain itu, implikatur juga sering kita temukan dalam penulisan kolom di surat kabar. Kolom merupakan salah satu bagian dalam surat kabar yang berisi tulisan-tulisan singkat dari redaktur sebuah surat kabar. Pada umumnya, kolom menampilkan tanggapan yang merupakan pendapat subjektif penulisnya untuk menanggapi berbagai persoalan aktual dan faktual yang berkembang di masyarakat. Salah satu kolom yang ditampilkan pada surat kabar adalah kolom pojok.

Wijana (2010: 120) menjelaskan wacana kolom pojok sebagai wacana kolom khusus yang terdapat di salah satu halaman pojok (sudut) sebuah surat kabar (harian atau mingguan). Dilihat dari strukturnya, wacana ini menampilkan berbagai variasi. Akan tetapi, yang paling umum wacana ini terdiri dari dua bagian, yakni situasi dan sentilan. Dalam sekali terbitan, lazimnya terdapat tiga atau empat wacana berstruktur situasi dan sentilan yang satu sama lain umumnya tidak berhubungan. Elemen situasi memberikan latar belakang mengenai peristiwa aktual yang sedang terjadi, pendapat atau kebijakan pemerintah atau aparat, dan sebagainya. Sementara itu, elemen sentilan merupakan komentar terhadap kejadian atau kebijakan itu. Komentar dalam hal ini mungkin merupakan pernyataan keprihatinan, simpati, kesetujuan, ketidaksetujuan, kritikan, saran dari sang penjaga pojok, dalam hal ini pihak redaktur harian bersangkutan (Wijana, 2010: 121).

Jika dicermati, wacana kolom pojok pada dasarnya juga merupakan representasi masyarakat dalam menanggapi beragam persoalan yang muncul di masyarakat. Melalui implikatur dalam sebuah wacana pojok, pembaca dapat mengetahui beragam persoalan yang sedang berkembang serta memahami bagaimana reaksi masyarakat pada umumnya terhadap persoalan tersebut. Hal ini menjadi penting untuk dipahami dalam rangka mengembangkan wawasan, pengetahuan, dan cara pandang masyarakat terhadap persoalanpersoalan aktual dan faktual di masyarakat.

Pemahaman terhadap implikatur wacana kolom pojok juga penting dimiliki oleh siswa Sekolah Menengah Atas (SMA). Hal ini lebih menjadi tuntutan dengan diimplementasikannya Kurikulum 2013 yang mengarahkan pembelajaran ke berbasis teks. Pembelajaran bahasa Indonesia yang berbasis teks salah satunya mensyaratkan tercapainya kompetensi memahami hingga memproduksi teks anekdot pada siswa kelas X. Anekdot merupakan cerita singkat yang menarik karena lucu dan mengesankan, biasanya mengenai orang penting atau terkenal dan berdasarkan kejadian yang sebenarnya (KBBI, 2013: 62). Anekdot pada umumnya mengandung sindiran yang bermaksud mengkritik berbagai persoalan yang terjadi di masyarakat, termasuk kebijakankebijakan pemerintah dan kebijakan-kebijakan layanan publik yang sering mendapat sorotan. Oleh sebab itu, untuk dapat menulis teks anekdot siswa harus memiliki pengalaman dan pengetahuan tentang beragam persoalan yang 
nyata terjadi di masyarakat. Hal ini sejalan dengan tema pembelajaran teks anekdot di kelas $\mathrm{X}$, yaitu 'Kritik dan Humor dalam Layanan Publik' yang bertujuan agar siswa dapat memahami teks anekdot dan dapat memanfaatkannya sebagai sarana untuk menyampaikan kritik terhadap persoalanpersoalan pada bidang-bidang layanan tersebut.

Pembelajaran teks anekdot di sekolah merupakan sesuatu yang baru. Umumnya siswa belum mengenal teks anekdot dan akan mengalami kesulitan ketika harus memproduksi teks anekdot. Kesulitan utama yang dihadapi oleh siswa adalah menemukan gagasan atau ide yang akan dikembangkan menjadi teks anekdot. Peristiwa yang terjadi di sekitar siswa tidak cukup untuk menjadi inspirasi dalam menentukan gagasan penulisan. Untuk itulah, wawasan siswa perlu lebih dikembangkan untuk memahami persoalan-persoalan aktual dan faktual yang lebih luas melalui membaca surat kabar. Wacana kolom pojok dapat menjadi salah satu rujukan yang digunakan siswa dalam rangka menemukan dan mengembangkan gagasan dalam penulisan teks anekdot. Selain itu, dengan membaca wacana kolom pojok diharapkan siswa akan lebih mengenal surat kabar sebagai salah satu sumber belajar dan sekaligus akan lebih meningkatkan minat baca siswa.

Penelitian yang telah dilakukan dan dianggap relevan dengan penelitian ini, di antaranya dilakukan oleh Firda Mustikawati pada tahun 2011 yang berjudul "Implikatur dalam Wacana Nuwun Sewu pada Surat Kabar Solopos." Penelitian ini membahas tentang wujud implikatur, fungsi penggunaan implikatur, dan gaya bahasa yang digunakan dalam kolom wacana Nuwun Sewu pada Surat Kabar Solopos. Penelitian ini menyimpulkan bahwa wujud implikatur yang hadir berupa gabungan dari kritik dan sindiran; gabungan antara pernyataan dan sindiran; gabungan antara perintah dan sindiran; pernyataan; gabungan antara pernyataan dan kritik; dukungan; protes; sindiran; gabungan antara apresiasi dan sindiran; gabungan antara pernyataan, kritik dan sindiran; perintah; gabungan antara pernyataan dan humor; gabungan antara larangan dan sindiran; gabungan antara sindiran dan humor; dan gabungan antara ajakan dan sindiran. Kemudian fungsi dari penggunaan implikaturnya berupa mengkritik dan menyindir, menyatakan dan menyindir, memerintah dan menyindir, mengapresiasi dan menyindir, memerintah, mengajak, melarang, dan menghibur. Kemudian gaya bahasa yang hadir adalah ironi, sinisme, asonansi, aliterasi, simile, metafora, hiperbola, metonimia, dan paradoks.

Persamaan antara penelitian ini dengan yang akan dilakukan terletak pada permasalahan yang akan dikaji yaitu implikatur. Selain itu, persamaan lainnya terletak pada penggunaan matriks fungsi implikatur. Sementara perbedaan penelitian tersebut dengan penelitian yang akan dilakukan terletak pada sumber datanya. Firda Mustikawati dalam penelitiannya, menggunakan wacana kolom Nuwun Sewu sebagai sumber data, sedangkan dalam penelitian ini menggunakan wacana kolom Mang Usil dalam Surat Kabar Harian Kompas.

Selanjutnya, penelitian lain yang relevan dengan penelitian ini yaitu dilakukan oleh Chyntia Radeani pada tahun 2015 dengan judul "Implikatur Pojok Mang Usil dalam Surat Kabar Kompas Edisi Juli-September 2011”. Penelitian tersebut membahas mengenai wujud implikatur dan maksud implikatur dalam kolom Mang Usil. Penelitian ini menyimpulkan bahwa wujud implikatur yang hadir berupa tindak tutur, yaitu implikatur representatif, implikatur ekspresif, dan implikatur direktif. Kemudian, maksud implikatur yang hadir yaitu berspekulasi, memberikan kesaksian, mengakui, menunjukkan, melaporkan, mengungkapkan, menyatakan, memberikan kritik, mengeluh, memberikan selamat, memuji, menyarankan, mengajak, dan meminta. Persamaan penelitian ini dengan sebelumnya terletak pada permasalahan yang dikaji yaitu mengenai implikatur dan juga terletak pada objek penelitiannya yaitu kolom Mang Usil. Perbedaan penelitian ini dengan penelitian sebelumnya terletak pada matriks penelitian yang digunakan.

Berdasarkan dari penjelasan di atas, peneliti merasa tertarik untuk melakukan penelitian tentang implikatur yang terdapat dalam wacana kolom Mang Usil dalam Surat Kabar Kompas dengan judul "Analisis Implikatur pada Kolom Mang Usil dalam Surat Kabar Harian Kompas dan Implikasinya dalam Pembelajaran bahasa Indonesia di SMA". Adapun alasan peneliti menggunakan kolom pojok yang ada di Kompas adalah karena surat kabar ini dikenal oleh semua orang dan surat kabar ini bersifat nasional sehingga mudah utuk mendapatkannya. Selain itu, wacana kolom 
Pojok di Kompas selalu menampilkan persoalanpersoalan aktual di masyarakat dengan dilengkapi komentar-komentar menarik dari redaktur surat kabar.

\section{METODE PENELITIAN}

Berdasarkan judul penelitian ini, yakni "Analisis Implikatur pada Kolom Mang Usil dalam Surat Kabar Harian Harian Kompas dan Implikasinya dalam Pembelajaran bahasa Indonesia di SMA", maka jenis penelitian ini termasuk penelitian deskriptif kualitatif, yaitu penelitian yang bertujuan untuk mendeskripsikan data, yaitu data yang berupa wujud implikatur dan fungsinya dalam kolom Mang Usil dan implikasinya dalam pembelajaran bahasa Indonesia di SMA.

Instrumen penelitian ini adalah peneliti sendiri (human instrument). Peneliti sebagai instrumen pengumpul serta penganalisis data. Peneliti berperan sebagai instrumen dengan mengedepankan kemampuan memproses data secepatnya serta memanfaatkan kesempatan untuk mengklarifikasi data (Moleong, 2005: 171). Penelitian ini menggunakan alat bantu berupa perangkat lunak. Perangkat lunak yang dimaksud berupa hal-hal tentang pengertian implikatur, indikator wujud implikatur dan fungsi implikatur.

Data dalam penelitian ini adalah wacana kolom pojok Mang Usil dalam Surat Kabar Harian Harian Kompas edisi Juni 2015 yang berjumlah 96 wacana dan sumber data dalam penelitian ini ialah Surat Kabar Harian Kompas edisi Juni 2015. Dalam penelitian ini, tahapan yang dilakukan antara lain: membaca dengan teliti dan berulang wacana kolom pojok Mang Usil dalam Surat Kabar Harian Kompas edisi Juni 2015 yang tampil secara heuristik, yakni pembacaan awal hingga akhir wacana secara berurutan, mencatat segala wujud implikatur dan fungsinya yang hadir pada wacana kolom pojok Mang Usil dalam Surat Kabar Harian Kompas edisi Juni 2015, pembacaan hermeneutik yakni membaca ulang setelah heuristika sehingga akan diketahui wujud dan fungsi implikatur pada wacana kolom pojok Mang Usil dalam Surat Kabar Harian Kompas edisi Juni 2015, meneliti wujud implikatur yang tampil dalam wacana kolom berdasarkan tabel instrumen penelitian, meneliti fungsi implikatur yang tampil dalam wacana kolom berdasarkan tabel instrumen penelitian, dan menarik simpulan dari permasalahan yang telah dibahas pada wacana kolom pojok Mang Usil dalam Surat Kabar Harian Kompas edisi Juni 2015.

\section{HASIL PENELITIAN}

Deskripsi hasil penelitian ini disesuaikan dengan tujuan penelitian yaitu (1) mendeskripsikan wujud implikatur pada Kolom Mang Usil dalam Surat Kabar Harian Kompas, (2) mendeskripsikan fungsi implikatur pada Kolom Mang Usil dalam Surat Kabar Harian Kompas, dan (3) mendeskripsikan implikasi hasil penelitian kepada pembelajaran bahasa Indonesia di SMA.

Wujud Implikatur dalam Kolom Pojok Mang Usil pada Surat Kabar Harian Kompas Edisi Juni 2015

Wujud implikatur pada kolom pojok Mang Usil dalam Surat Kabar Harian Kompas edisi Juni 2015 diarahkan pada realisasi maksud tanggapan redaktur pada wacana kedua menurut ciri strukturalnya. Dalam bahasa Indonesia, tuturan secara struktural terdiri atas kalimat deklaratif, imperatif, dan kalimat interogatif.

Ketiga bentuk kalimat tersebut didapatkan dalam penelitian ini.

\section{Wujud Implikatur Berupa Kalimat Deklaratif}

Kalimat deklaratif adalah kalimat yang mengandung maksud memberitahukan sebuah informasi kepada mitra tutur. Dalam penelitian ini, ditemukan dua jenis wujud implikatur yang berupa kalimat deklaratif. Kedua jenis wujud tersebut dijelaskan sebagai berikut.

\section{Kalimat Deklaratif Aktif}

Kalimat deklaratif aktif adalah kalimat yang subjeknya menjadi pelaku dari perbuatan yang menjadi predikat kalimat. Data tuturan wujud implikatur berupa kalimat deklaratif aktif dipaparkan sebagai berikut. 
Sikap kenegarawanan pudar.

Yang mencorong halalkan segala cara. (Kompas, 9 Juni 2015)

\section{Konteks tuturan:}

Tuturan dalam wacana kedua tersebut memperlihatkan sikap pemerintah di Indonesia sekarang yang tidak mencerminkan sikap seorang negarawan. Bahkan, mereka lebih mementingkan diri sendiri dan menghalalkan segala cara untuk memenuhi keinginannya. Contoh kecilnya pada politik privatisasi air.

Data di atas termasuk kalimat deklaratif aktif. Hal itu ditandai dengan subjek yang berperan sebagai pelaku. Kemudian, awalan predikat juga menggunakan awalan me- yang menjadi penanda sebuah kalimat deklaratif aktif. Sebagai kalimat deklaratif aktif, tuturan tersebut bermaksud menyatakan bahwa sikap pemerintah sudah tidak mencerminkan sikap negarawan. Pimpinan Pusat Muhammadiyah, Haidar Nasir, dalam pertemuan dengan Ketua MPR, Zulkifli Hasan, di Kantor PP Muhammadiyah, Yogyakarta, mengatakan bahwa pemerintah sudah tidak mencerminkan sikap negarawan. Hal itu terlihat dari pengambilan kebijakan yang bertentangan dengan tujuan kemerdekaan, seperti pada pengambilan kebijakan privatisasi sumber daya alam yang bisa merugikan masyarakat banyak dan hanya menguntungkan segelintir orang.

\section{Kalimat Deklaratif Pasif}

Kalimat deklaratif pasif adalah kalimat yang subjeknya berperan sebagai penderita akibat perbuatan yang menjadi predikat kalimat. Biasanya predikat diawali dengan awalan $d i-$. Data tuturan wujud implikatur berupa kalimat deklaratif pasif dipaparkan sebagai berikut.

Masyarakat didorong ikut awasi pilkada serentak.

\section{Biasa cuma dianggap penonton.}

(Kompas, 5 Juni 2015)

\section{Konteks tuturan:}

Tuturan tesebut berkenaan dengan nasib masyarakat yang tidak dianggap dalam pilkada. Mereka sering hanya dijadikan penonton. Hal itu terlihat dari laporan dugaan kecurangan PEMILU 2014 yang datang dari panitia pengawas PEMILU dan bukan dari masyarakat.

Data tersebut termasuk dalam kalimat deklaratif pasif. Hal itu ditandai dengan penggunaan awalan $d i$ - pada predikat verba kalimatnya dan juga subjeknya menjadi penderita. Sebagai kalimat deklaratif pasif, kalimat tanggapan tersebut diungkapkan dengan maksud menyatakan bahwa status masyarakat sebagai pengawas dalam pilkada belum terlalu dimaksimalkan, bahkan mereka sering dianggap tidak ada. Hal itu terlihat pada hasil Pemilu 2014 yang menyebutkan bahwa laporan kecurangan pemilu banyak datang dari petugas, bukan dari masyarakat.

\section{Wujud Implikatur Berupa Kalimat Imperatif}

Kalimat imperatif atau kalimat perintah adalah kalimat yang maknanya menyuruh atau meminta orang lain untuk melakukan sesuatu seperti yang diinginkan oleh penutur. Penanda dari kalimat ini adalah tanda seru (!) di akhir kalimatnya.

Dalam penelitian ini ditemukan dua jenis kalimat imperatif, yaitu kalimat imperatif biasa dan kalimat imperatif larangan. Kedua jenis kalimat imperatif tersebut dipaparkan sebagai berikut.

\section{Kalimat Imperatif Biasa}

Kalimat imperatif biasa adalah kalimat yang lazimnya memiliki ciri-ciri berintonasi keras, didukung dengan kata kerja dasar, dan biasanya berpartikel -lah. Kalimat imperatif jenis ini dapat berkisar antara imperatif yang sangat halus sampai dengan imperatif yang sangat kasar. Data tuturan wujud implikatur berupa kalimat imperatif biasa dipaparkan sebagai berikut.

Parpol berkomitmen hilangkan "mahar" di pilkada.

Enggak janji, deh!

(Kompas, 8 Juni 2015)

\section{Konteks tuturan:}

Tuturan tersebut tentang komitmen parpol yang belum dapat dipercaya untuk menghilangkan mahar dalam pilkada.

Data tersebut termasuk ke dalam kalimat imperatif biasa. Hal itu ditandai dengan intonasi akhir dari tuturan tersebut yang keras dan kata kerja dalam kalimat tersebut menggunakan kata dasar. Selain itu, akhir dari kalimat menggunakan tanda baca seru Sebagai kalimat imperatif biasa, kalimat tersebut bermaksud menyatakan bahwa komitmen parpol untuk menghilangkan mahar dalam pilkada tidak dapat 
dipastikan. Bisa saja hal tersebut hanya janji belaka.

\section{Kalimat Imperatif Larangan}

Kalimat imperatif larangan adalah kalimat yang digunakan untuk mencegah orang lain melakukan sesuatu. Dalam penelitian ini, tuturan berupa kalimat imperatif larangan untuk melakukan sesuatu dapat dipaparkan sebagai berikut.

Pemerintah perlu luruskan sejarah Bung Karno.

“Jas merah!” Kata Bung Karno.

(Kompas, 8 Juni 2015)

\section{Konteks tuturan:}

Tuturan tersebut menanggapi tentang presiden yang salah dalam menyebutkan tempat kelahiran Ir. Soekarno sehingga perlu meluruskan sejarah.

Data tersebut merupakan kalimat imperatif larangan. Hal itu terlihat dari penanda gramatikal, yaitu penggunaan kata jangan dalam jargon Jas merah yang berarti jangan sekali-kali melupakan sejarah. Penggunaan kata jangan dalam kalimat itu berfungsi melarang. Sebagai kalimat imperatif larangan, kalimat itu bermaksud mengimbau dan melarang seluruh lapisan rakyat Indonesia untuk melupakan sejarah.

\section{Wujud Implikatur Berupa Kalimat Interogatif}

Kalimat interogatif adalah kalimat yang mengandung maksud menanyakan sesuatu kepada mitra tutur. Sesuatu yang dimaksud bisa berupa pengakuan, keterangan, alasan atau pendapat dari penutur. Kalimat ini memiliki ciri-

ciri, diantaranya (a) pola intonasinya bernada akhir naik, (b) pada umumnya menggunakan kata tanya, dan (c) dapat menggunakan partikel tanya $-k a h$.

Dalam penelitian ini, ditemukan beberapa contoh kalimat interogatif dalam tanggapan redaktur. Kalimat-kalimat tersebut diapaparkan sebagai berikut.

Dua kubu Golkar sepakat islah.

Bukan akal-akalan kan?

(Kompas, 1 Juni 2015)

Konteks tuturan:

Tuturan tersebut berkaitan dengan tindakan dua kubu di Golkar yang sepakat melakukan islah, namun islah yang dilakukan adalah islah khusus. Hal ini menimbulkan kesan bahwa tindakan yang dilakukan hanya akal-akalan untuk dapat ikut dalam pilkada serentak.

Data tersebut merupakan kalimat interogatif. Hal itu terlihat dari akhir kalimat yang menggunakan tanda tanya. Sebagai kalimat interogatif, tuturan tersebut bermaksud mempertanyakan alasan dibalik islahnya kedua kubu dalam tubu Partai Golkar. Sangat kuat dugaan, bahwa islah yang dilakukan hanyalah akal-akalan untuk bisa mengikuti pilkada serentak pada Desember 2015.

Fungsi Implikatur dalam Kolom Pojok Mang Usil pada Surat Kabar Harian Kompas Edisi Juni 2015

Berdasarkan dari matriks yang menjadi acuan dalam penelitian ini, diperoleh beberapa fungsi implikatur yaitu fungsi berupa pernyataan, sindiran, kritik, apresiasi, dukungan, larangan, dan perintah. Ketujuh fungsi impikatur tersebut akan dipaparkan sebagai berikut.

\section{Fungsi Berupa Pernyataan}

Fungsi implikatur berupa pernyataan yaitu menyatakan sesuatu yang ingin disampaikan kepada pihak tertentu secara tersirat. Hal ini ditandai dengan tuturan yang berupa kalimat berita yang diakhiri dengan tanda baca titik. Data mengenai fungsi pernyataan dipaparkan sebagai berikut.

SBY ingin modernisasi Partai Demokrat.

Masih banyak asal Bapak senang, ya, Pak.

(Kompas, 1 Juni 2015)

Situasi atau konteks wacana tersebut tentang Susilo Bambang Yudhoyono yang terpilih sebagai Ketua Umum Partai Demokrat menginginkan modernisasi pada partainya yang menyangkut infrastruktur, kultur, maupun kaderisasi. Dalam hal ini muncul tanggapan masih banyak asal Bapak senang, ya, Pak pada wacana kedua.

Tanggapan pada wacana kedua berfungsi untuk menyatakan bahwa dukungan dari seluruh lapisan partai diberikan kepada SBY dalam menjalankan tugas dan tanggung jawabnya. Kata banyak dalam tanggapan mengimplikasikan ribuan kader yang 
mendukung SBY dalam memimpin Partai Demokrat.

\section{Fungsi Berupa Sindiran}

Fungsi implikatur berupa sindiran adalah menyindir dengan halus agar tidak menyinggung perasaan pihak tertentu. Biasanya sindiran dikeluarkan dengan nada mengejek. Fungsi sindiran dapat hadir dalam beraneka ragam wujud, baik dalam wujud deklaratif, imperatif, maupun interogatif. Data fungsi implikatur berupa sindiran dipaparkan sebagai berikut.

Tiga nama dari Polri dicalonkan jadi anggota KPK.

Disusupkan?

(Kompas, 16 Juni 2015)

Situasi atau konteks wacana tersebut tentang tiga nama dari Polri dicalonkan menjadi anggota KPK. Dalam hal ini, muncul tanggapan disusupkan pada wacana kedua.

Tanggapan tersebut yang diwujudkan dalam bentuk kalimat interogatif atau pertanyaan berfungsi menyindir tindakan Polri yang mencalonkan tiga nama untuk menjadi anggota KPK. Anggota Kompolnas, Adrianus Meliala mengatakan bahwa sebaiknya pencalonan seseorang untuk menjadi anggota KPK dilandasi oleh dorongan pribadi, bukan dorongan institusi karena jangan sampai timbul kesan bahwa tiga nama yang dicalonkan oleh Polri untuk menjadi anggota KPK merupakan titipan Polri.

\section{Fungsi Berupa Kritikan}

Kritik merupakan tuturan yang berisi analisis, interpretasi, dan penilaian terhadap baik dan buruknya sesuatu. Fungsi implikatur berupa kritikan adalah mengkritik pihak-pihak tertentu secara tersirat. Data fungsi implikatur berupa kritikan dipaparkan sebagai berikut.

Ribuan anak balita di NTT kekurangan gizi dan bergizi buruk.

Habis disedot koruptor

(Kompas, 24 Juni 2015)

Situasi atau konteks wacana tersebut tentang ribuan anak balita yang menderita kekurangan gizi dan bergizi buruk di NTT.
Dalam hal ini, muncul tanggapan habis disedot para koruptor pada wacana kedua.

Tanggapan tersebut yang diwujudkan dalam bentuk kalimat pernyataan bermaksud menyatakan bahwa anak balita di NTT banyak yang mengalami gizi buruk, bahkan menurut Direktur Perkumpulan Inisiatif dan Advokasi Rakyat NTT, Sarah Lery Mboik, persoalan tersebut sudah berlangsung sejak 20 tahun silam dan tidak pernah berubah sampai hari ini. Selain berisi pernyataan, tanggapan redaktur juga mengandung kritik kepada pemerintah NTT yang dari dahulu sampai sekarang tidak mampu menanggulangi masalah gizi buruk di NTT, bahkan dana APBD sering diselewengkan oleh pemerintah daerah dengan anggota DPRD untuk kepentingan mereka sendiri melalui sejumlah proyek siluman.

\section{Fungsi Berupa Apresiasi}

Apresiasi adalah tuturan yang bermaksud memberi penghargaan terhadap sesuatu. Fungsi implikatur berupa apresiasi memberikan apresiasi kepada pihak tertentu. Dalam hal implikatur, bentuk tuturan apresiai ini disampaikan secara tersirat. Data fungsi implikatur berupa apresiasi dipaparkan sebagai berikut.

Awak kabin Garuda terbaik di dunia. Juga berkat keramahan pramugarinya.

(Kompas, 18 Juni 2015)

Situasi atau konteks wacana tersebut tentang Garuda yang mendapat penghargan sebagai awak kabin terbaik di dunia. Dalam hal ini, muncul tanggapan juga berkat keramahan pramugarinya pada wacana kedua.

Tanggapan tersebut yang diwujudkan dengan kalimat pernyataan berfungsi memberi apresiasi kepada pihak Garuda yang kembali mengharumkan nama Indonesia di kancah internasional dalam hal pelayanan maskapai penerbangan. Penghargaan yang diberikan oleh Skytrax merupakan penghargaan yang diterima kedua kalinya oleh Garuda. Penghargaan serupa diterima oleh maskapai tersebut tahun lalu.

\section{Fungsi Berupa Dukungan}

Fungsi implikatur berupa dukungan yaitu mendukung secara tidak langsung kepada 
pihak tertentu. Data fungsi implikatur berupa dukungan dipaparkan sebagai berikut.

Digelar, kampanye damai lewat media sosial.

Biar enggak cuma buat nyinyir.

(Kompas, 12 Juni 2015)

Situasi atau konteks wacana tersebut tentang kampanye perdamaian yang dapat dilakukan lewat media sosial. Kampanye tersebut diusung dalam temu jurnalis, blogger, dan penulis 2015 di Jakarta, Rabu, 10 Juli 2015. Dalam hal ini, muncul tanggapan biar enggak Cuma buat nyinyir pada wacana kedua.

Tanggapan redaktur pada wacana kedua yang diungkapkan dengan kalimat pernyataan bermaksud mendukung gerakan yang dilakukan oleh para jurnalis, bloger, dan penulis tersebut karena media sosial sekarang selalu diisi dengan hal-hal yang tidak penting. Dengan adanya temu jurnalis, blogger, dan penulis, diharapkan media sosial dapat diisi dengan tulisan-tulisan yang berisi penyebaran kebaikan.

\section{Fungsi Berupa Larangan}

Fungsi impikatur berupa larangan adalah Melarang pihak tertentu untuk melakukan sesuatu. Biasanya ditandai dengan kata jangan. Data fungsi implikatur berupa larangan dipparkan sebagai berikut.

Ketua DPD: Ada upaya melemahkan KPU Jangan ada yang lempar batu, sembunyi tangan!

(Kompas, 23 Juni 2015)

Situasi atau konteks wacana tersebut tentang pernyataan Ketua DPD yang menyebutkan ada upaya melemahkan KPU, bahkan hal itu berdampak pada rancana penundaan pilkada. Dugaan tersebut muncul ketika hasil pemeriksaan Badan Pemeriksa Keuangan terhadap KPU disinyalir sengaja didorong ke arah penundaan pilkada. Dalam hal ini, muncul tanggapan jangan ada yang lempar batu, sembunyi tangan pada wacana kedua.

Tanggapan tersebut yang diwujudkan dalam bentuk kalimat imperatif atau perintah berfungsi melarang semua pihak untuk tidak lempar batu sembunyi tangan atau melakukan sesuatu dan tidak mengakuinya.

\section{Fungsi Berupa Perintah}

Perintah adalah tuturan yang bertujuan memberikan perintah kepada lawan tutur yang biasanya ditandai dengan partikel -lah. Fungsinya yaitu menyuruh untuk mengerjakan sesuatu. Bentuk tuturan yang menyatakan perintah disampaikan kepada pihak tertentu secara tersirat. Data fungsi implikatur berupa perintah dipaprkan sebagai berikut.

Presiden pimpin rapat kabinet tentang pengelolaan sampah.

Jangan sampai dijuluki negeri sampah.

(Kompas, 25 Juni 2015)

Situasi atau konteks wacana tersebut tentang presiden yang memimpin rapat kabinet mengenai pengelolaan sampah. Dalam hal ini, muncul tanggapan jangan sampai dijuluki negeri sampah pada wacana kedua.

Tanggapan redaktur pada wacana kedua tersebut yang diungkapkan dengan kalimat deklaratif berisi perintah secara tidak langsung kepada pemerintah agar betul-betul memperhatikan kondisi sampah di Indonesia. Pemerintah diharap mampu menemukan solusi penanganan sampah yang baik seperti di Jerman, Singapura, dan Korea Selatan. Jika penanganan sampah tidak dilakukan dengan baik, bisa jadi Indonesia akan menjadi negeri sampah dengan perkiraan di tahun 2019 Indonesia memproduksi 67,1 ton sampah.

\section{Implikasi pada Pembelajaran Bahasa Indonesia di SMA}

Hasil penelitian menunjukkan bahwa pada umumnya wacana kolom pojok dimaksudkan untuk menyampaikan kritik, sindiran, dan lain-lain terhadap berbagai kebijakan yang bersentuhan dengan masyarakat, persoalan penegakan hukum dan aturan-aturan yang berlaku di masyarakat, bentuk-bentuk layanan yang semestinya dinikmati masyarakat, dan berbagai persoalan lain meliputi persoalan sosial, ekonomi, maupun politik. Selanjutnya hasil penelitian ini dapat diimplikasikan pada pembelajaran bahasa Indonesia di SMA. Sesuai dengan Kurikulum 2013, pembelajaran bahasa Indonesia adalah berbasis teks. Salah satu jenis teks yang dibelajarkan adalah teks anekdot. Teks anekdot merupakan teks yang memaparkan 
cerita singkat yang menarik karena lucu dan mengesankan yang isinya berupa kritik atau sindiran terhadap kebijakan, layanan publik, perilaku penguasa, atau suatu fenomena/kejadian. Tujuan teks anekdot adalah memberikan sindiran/kritik terhadap kebijakan, layanan publik, perilaku penguasa, atau suatu fenomena/kejadian dengan cara yang lebih menghibur dan menarik (lucu dan mengesankan) (Priyatni, 2014: 93).

Wacana kolom pojok memiliki karakteristik yang sama dengan teks anekdot. Keduanya digunakan untuk menyampaikan kritik terhadap kebijakan, layanan publik, dan lain-lain dengan menggunakan sindiran. Adanya persamaan karakteristik ini dapat dijadikan sebagai dasar untuk mengimplikasikan hasil penelitian ini pada pembelajaran teks anekdot. Pembelajaran memproduksi teks anekdot pada SMA kelas X terdapat pada KD 4.2 Memproduksi teks anekdot yang koheren sesuai dengan karakteristik teks yang akan dibuat baik secara lisan maupun tulisan. Adapun tema yang digunakan dalam membelajarkan KD ini adalah 'Kritik dan Humor dalam Layanan Publik' yang bertujuan agar siswa dapat memahami teks anekdot dan dapat memanfaatkannya sebagai sarana untuk menyampaikan kritik terhadap persoalan-persoalan pada bidang-bidang layanan tersebut.

\section{KESIMPULAN}

Berdasarkan hasil penelitian dan pembahasan mengenai implikatur dalam kolom Mang Usil pada Surat Kabar Kompas, dapat disimpulkan beberapa hal sebagai berikut.

1. Wujud implikatur yang ditemukan dalam kolom Mang Usil pada Surat Kabar Harian

\section{DAFTAR PUSTAKA}

Achmad dan Alek Abdullah. 2012. Linguistik Umum. Jakarta: Erlangga.

Agustriana, Sara. 2012. Pemahaman Tentang Tajuk Rencana, Karikatur, dan Pojok. (online). http://agustrianasara.blogspot.com/2012/06/i nformasi-mengenai-tajuk-

rencana.html?m=1. Diakses 30 Mei 2015.
Kompas berupa (1) kalimat deklaratif, (2) kalimat imperatif, dan (3) kalimat interogatif. Wujud berupa kalimat deklaratif yang ditemukan ada dua jenis yaitu (1) kalimat deklaratif aktif dan (2) kalimat deklaratif pasif. Wujud berupa kalimat imperatif yang ditemukan ada dua jenis yaitu (1) kalimat imperatif biasa dan (2) kalimat imperatif larangan.

2. Fungsi implikatur yang ditemukan dalam kolom Mang Usil pada Surat Kabar Harian Kompas yaitu fungsi implikatur berupa pernyataan, fungsi implikatur berupa sindiran, fungsi implikatur berupa kritikan, fungsi implikatur berupa apresiasi, fungsi implikatur berupa dukungan, fungsi implikatur berupa larangan, dan fungsi implikatur berupa perintah.

3. Hasil penelitian ini dapat diimplikasikan dalam pembelajaran bahasa Indonesia di SMA. Salah satunya sebagai sumber belajar alternatif dalam pembelajaran memproduksi teks anekdot pada siswa SMA kelas X sesuai dengan KD 4.2 Memproduksi teks anekdot yang koheren sesuai dengan karakteristik teks yang akan dibuat baik secara lisan maupun tulisan. Selain lebih mudah menemukan persoalan-persoalan aktual dan faktual yang sedang berkembang di masyarakat, melalui kolom pojok siswa juga akan memperoleh gambaran cara yang dapat digunakan untuk menyampaikan kritik melalui sindiran. Di samping itu, dengan berkembangnya wawasan siswa mengenai berbagai persoalan yang ada di masyarakat, siswa akan lebih mudah menemukan ide atau gagasan penulisan yang selanjutnya dapat dikembangkan menjadi sebuah teks anekdot.

Amiruddin. 2014. "Implikatur yang Terungkap Melalui Percakapan Tokoh Roman Azab dan Sengsara dan Penerapannya dalam Pengajaran Bahasa Indonesia Siswa Kelas XI SMA Negeri Sidenreng Rappang”. Tesis. Tidak Diterbitkan. Makassar: Program Pascasarjana Universitas Negeri Makassar.

Arifin. 2002. "Implikatur Percakapan Pelaku dalam Bahasa Indonesia pada Teks Lakon Sumur Tanpa Dasar Karya Arifin C. Noer (Suatu Kajian Pragmatik)". Tesis. Tidak 
Diterbitkan. Makassar: Program Pascasarjana Universitas Hasanuddin.

Aslinda dan Leni Syafyahya. 2010. Pengantar Sosiolinguistik. Bandung: Refika Aditama.

Chaer, Abdul dan Leoni Agustina. 1995. Sosiolinguistik. Jakarta: Rineka Cipta.

Chaer, Abdul. 2009. Sintaksis Bahasa Indonesia (Pendekatan Proses). Jakarta: Rineka Cipta . 2010. Kesantunan Berbahasa. Jakarta: Rineka Cipta. . 2012. Linguistik Umum. Jakarta: Rineka Cipta.

Cummings, L. 2007. Pragmatik Sebuah Perspektif Multidisipliner. Yogyakarta: Pustaka Pelajar.

Darmadi, Hamid. 2009. Kemampuan Dasar Mengajar. Bandung: Alfabeta

Departemen Pendidikan Nasional. 2013. Kamus Besar Bahasa Indonesia Edisi Keempat. Jakarta: Gramedia Pustaka Utama.

Djadjasudarma, T.F. 2010. Wacana. Bandung: Refika Aditama.

Eriyanto. 2012. Analisis Wacana Pengantar Analisis Teks Media. Yogyakarta: LkiS Printing Cemerlang.

Halliday, M.A.K. 1992. Bahasa, Konteks, dan Teks. Yogyakarta: Gajah Mada University Press.

Harmina, Andi. 2010. "Implikatur Verbal Pujian Bahasa Indonesia dalam Interaksi Belajar Mengajar di SMA Negeri 1 Pammana". Tesis. Tidak Diterbitkan. Makassar: Program Pascasarjana Universitas Muhammadiyah Makassar.

Kridalaksana. 2008. Kamus Linguistik. Edisi Revisi. Jakarta: Gramedia Pustaka Utama.

Leech, G. 1993. Prinsip-Prinsip Pragmatik. Jakarta: Indonesia University Press.

Lubis, Hamid Hasan. 2011. Analisis Wacana Pragmatik. Bandung: Angkasa.

Mahsun. 2005. Metode Penelitian Bahasa: Tahapan Strategi, Metode, dan Tekniknya. Jakarta: Raja Grafindo.

Moeliono, A. (Eds). (1993). Tata Bahasa Baku Bahasa Indonesia. Jakarta: Balai Pustaka.

Moleong, L. J. 2005. Metodologi Penelitian Kualitatif. Edisi Revisi. Cetakan Keduapuluhsatu. Bandung: Remaja Rosdakarya.

Mulyana. 2005. Kajian Wacana. Yogyakarta: Tiara Wacana.

Mulyasa, Enco. 2012. Standar Kompetensi dan Sertifikasi Guru. Bandung: Rosdakarya.

Muslich, Masnur. 2007. Kurikulum Tingkat Satuan Pendidikan. Bandung: Rosdakarya.

Mustikawati, Firda. 2007. "Implikatur dalam Wacana nuwun Sewu pada Surat Kabar Solopos.” Skripsi. Tidak Diterbitkan. Yogyakarta: Universitas Negeri Yogyakarta.
Muzayin, Ahmad Abab. 2010. "Implikatur Percakapan Guru dan Siswa dalam Interaksi Belajar mengajar di SMA Negeri 5 Makassar". Tesis. Tidak Diterbitkan. Makassar: Program Pascasarjana Universitas Negeri Makassar.

Nababan, P.W.J. 1987. Ilmu Pragmatik (Teori dan Penerapannya). Jakarta: DEPDIKBUD.

Priyatni, Endah Tri. 2014. Desain Pembelajaran Bahasa Indonesia dalam Kurikulum 2013. Jakarta: Bumi Aksara.

Rahardi, Kuncana. 2000. Imperatif dalam Bahasa Indonesia. Yogyakarta: Duta Wacana University Press

Rahardi, Kuncana. 2005. Pragmatik: kesantunan Imperatif Bahasa Indonesia. Jakarta: Erlangga.

Rani, Abdul, dkk. 2005. Analisis Wacana. Malang: Banyu Media Publishing.

Rosidi, I. 2009. Contoh Proposal Penelitian: Bentuk Implikatur dalam Kegiatan Transaksi di Koperasi Siswa SMKN kota Pasuruan, http:/guruumarbakrie.blogspot.com/. (Diakses pada tanggal 20 April 2015).

Sobur, A. 2008. Membaca "Pojok" Koran. Jurna Mediator Vol. 9.

Sumarsono. 2012. Sosiolinguistik. Yogyakarta: Sabda.

Tarigan, Henry Guntur dan Djago Tarigan. 2009. Telaah Buku Teks Bahasa Indonesia. Bandung: Penerbit Angkasa.

Tarigan, H. G. 2009. Pengajaran Pragmatik. Bandung: Angkasa.

Usman. 2005. "Tindak Ilokusi Bahasa Indonesia Dakwah K.H. Abdullah Gymnastiar dalam Siaran Televisi" Tesis. Tidak Diterbitkan. Malang: Program Pascasarjana Universitas Negeri Malang.

Wijana, I.D.P. 1995. "Pemanfaatan Teks Humor dalam Pegajaran Aspek- Aspek Kebahasaan", II/1995. Halaman 23-30.

Wijana, I.D.P dan Muhammad Rohmadi. 2010. Analisis Wacana Pragmatik. Surakarta: Yuma Pustaka.

Yule, G. 2006. Pragmatics. England: Oxford University Press (Terjemahan dalam Bahasa Indonesia oleh Indah Fajar Wahyuni). Pragmatik. Yogyakarta: Pustaka Pelajar.

Yustinawati, Nelly. 2015. "Implikatur pada Wacana Kolom Pojok dalam Surat Kabar Lampung Post dan Implikasinya dalam Pembelajaran Teks Anekdot di SMA”. Tesis. Lampung: Program Pascasarjana Universitas Lampung.

Zamzani. 2007. Kajian Sosiopragmatik. Yogyakarta: Cipta Pustaka. 